ARCHEION, T. CXX

WARSZAWA 2019

ISSN 0066-6041

e-ISSN 2658-1264

DOI 10.4467/26581264ARC.19.011.11820

RADOSŁAW GAZIŃSKI

ORCID $\underline{\text { 0000-0002-6734-9309 }}$

r.gazinski@bg.szczecin.pl

(Uniwersytet Szczeciński)

\title{
ARCHIWA KSIĄŻĄT GRYFITÓW OD POCZĄTKÓW XVI DO POŁOWY XVII W.
}

Slowa kluczowe: archiwa książęce, Gryfici, epoka nowożytna

\section{Streszczenie}

W okresie nowożytnym na Pomorzu ukształtowało się sześć archiwów książęcych. Pierwsze dwa (szczecińskie i wołogoskie) powstały w wyniku podziału państwa pomorskiego w 1532 r. Po 1557 r. doszło do nich archiwum książąt-biskupów funkcjonujące w Koszalinie. Natomiast po wykształceniu się w osobne instytucje książęcych sądów nadwornych (po 1575 r.) do trzech wspomnianych archiwów (wołogoskiego, szczecińskiego i biskupiego) doszły trzy archiwa sądowe. Wszystkie one podlegały odpowiednim kanclerzom terytorialnym. Na ich czele stał najczęściej wykształcony urzędnik w randze radcy sądowego lub sekretarza kancelarii. Archiwa książęce były posadowione w stolicach poszczególnych władztw w głównych rezydencjach Gryfitów (zamki w Wołogoszczy, Szczecinie i Koszalinie). Były one pilnie strzeżone, a dostęp do nich był ograniczony. Archiwa książęce nie tylko przechowywały spuściznę po Gryfitach, ale także wspierały prowadzoną przez nich politykę wewnętrzną i zagraniczną. Ponadto książęta zdawali sobie sprawę z wagi archiwów jako skarbnic wiedzy o dynastii, które można wykorzystywać (poprzez publikacje) do wzmocnienia prestiżu Gryfitów w Europie. Mimo dość szczupłego personelu utrzymywano w archiwach należyty porządek, dbano także o ewidencję zasobu. Świadczyć o tym mogą chociażby dość częste skontra zasobów poszczególnych archiwów rejestrujące ich aktualny stan posiadania. Należy także dodać, że obok archiwów państwowych i sądowych każdy z Gryfitów posiadał większe lub mniejsze archiwum prywatne (najczęściej korespondencja i rachunki), które po śmierci każdego z książąt włączano do archiwum danego władztwa. Po wymarciu w 1626 r. wołogoskiej linii Gryfitów oraz w związku z zagrożeniem wojennym Pomorza Bogusław XIV podjął decyzję o centralizacji w Szczecinie wszystkich archiwaliów książęcych. W rzeczywistości poza dostarczeniem na szczeciński zamek niewielkich partii dokumentów i akt z Wołogoszczy (1628 r.) i Koszalina (1635 r.) archiwalia książęce do czasu śmierci Bogusława XIV (1637 r.) pozostawały w rozproszeniu. Dopiero w 1639 r. Szwedzi zwieźli je do Szczecina, a następnie w 1642 r. uporządkowali. Po zakończeniu wojny trzydziestoletniej (1648 r.) strona brandenburska zaczęła domagać się od Szwedów przekazania jej akt poksiążęcych niezbędnych do zarządzania przejętą częścią Pomorza. Szwedzi początkowo się opierali. Dopiero pełna normalizacja wzajemnych stosunków, a następnie reces graniczny (1653 r.) spowodowały wydzielenie przez administrację szwedzką z akt przechowywanych w Szczecinie partii archiwaliów przekazanych pod koniec 1653 r. Brandenburczykom. Od tej pory na Pomorzu działały dwa archiwa przechowujące akta poksiążęce: szwedzkie w Szczecinie i brandenburskie w Kołobrzegu. 
RADOSŁAW GAZIŃSKI

ORCID 0000-0002-6734-9309

r.gazinski@bg.szczecin.pl

(University of Szczecin)

\title{
ARCHIVES OF THE GRIFFIN DUKES FROM THE EARLY SIXTEENTH TO THE MID-SEVENTEENTH CENTURY
}

Keywords: princedom archives, House of Griffin, modern era

\begin{abstract}
Archives of the Griffins in modern times. In the modern period, six ducal archives were formed in Pomerania. The first two (Stettin and Wolgast) were created as a result of the division of the Pomeranian state in 1532. After 1557, the archives of prince-bishops were established in Koszalin. However, after the formation of ducal courts of justice as separate institutions (after 1575), three court archives were added to the three above-mentioned ones (the Wolgast, Stettin and bishopric). They were all under the authority of respective territorial chancellors. They were most often headed by an educated clerk in the rank of court counsellor or secretary of the office. Ducal archives were located in the capitals of particular jurisdictions in the main residences of the Griffins (castles in Wolgast, Stettin and Koszalin). They were closely guarded and access to them was limited. Ducal archives not only preserved the legacy of the Griffins, but also supported their domestic and foreign policy. Moreover, the dukes were aware of the importance of the archives as a treasury of knowledge about the dynasty, which could be used (through publications) to strengthen the prestige of the House of Griffin in Europe. Despite rather slim staffing, the archives were kept in good order, and the records of the stock were also taken care of. Evidence of this can be seen in fairly frequent inventory scans of individual archives recording their current holdings. It should also be added that besides the state and court archives, each of the Griffin dukes had a larger or smaller private archive (usually correspondence and bills), which after the death of each of the dukes was incorporated into the archives of the given jurisdiction. After the extinction of the Wolgast line of Griffins in 1626 and due to the danger of war in Pomerania, Boguslav XIV decided to centralize all the ducal archives in Szczecin. In fact, however, except for small portions of documents and files from Wolgost (1628) and Koszalin (1635) transferred to the Szczecin castle, the ducal archives remained scattered until Boguslav XIV's death (1637). It was not until 1639 that the Swedes took them to Szczecin, and subsequently sorted and arranged them in 1642. After the end of the Thirty Years' War (1648), the Brandenburg side began to demand that the Swedes hand over the post-ducal records necessary to manage the captured part of Pomerania. The Swedes initially resisted. It was only the full normalisation of mutual relations and then the border recession (1653) that convinced the Swedish administration to separate a batch of archival records from those stored in Szczecin and to hand them over to the Brandenburgers in late 1653. Since then, there have been two archives in Pomerania preserving the post-ducal records: the Swedish one in Szczecin and the Brandenburg one in Kołobrzeg.
\end{abstract}


Archiwa Gryfitów, dynastii książęcej panującej na Pomorzu od początków XII w. (Warcisław I) po lata 30. XVII w. (Bogusław XIV), nie doczekały się do tej pory szerszego opracowania. Jedynie w 1835 r. pierwszy dyrektor szczecińskiego królewskiego archiwum Ludwik v. Medem, opisując nowo powstałą placówkę, cofnął się w swoich rozważaniach do czasów Gryfitów ${ }^{1}$. W powojennej literaturze polskiej jedynie w wydawanych przez Archiwum Państwowe w Szczecinie okolicznościowych publikacjach można znaleźć podstawowe informacje o archiwach funkcjonujących w czasach książęcych ${ }^{2}$. Ze szczecińskich archiwistów tylko Jerzy Podralski opublikował niewielki artykuł o Jacobie Froście, opiekunie szczecińskiego książęcego archiwum w pierwszych dekadach XVII w. ${ }^{3}$ Ten sam archiwista w 1977 r. opracował zespół archiwalny: Archiwum Książąt Szczecińskich, pisząc przy tym bardzo wartościowy wstęp do inwenta$\mathrm{rza}^{4}$. Jest on również autorem przewodnika po zespole Archiwum Książąt Szczecińskich $^{5}$. Zespół Archiwum Książąt Wołogoskich został opracowany dopiero w 2003 r. przez Annę Lazarek, która we wstępie do inwentarza podała wiele interesujących informacji o wołogoskim archiwum ${ }^{6}$.

Artykuł ma za zadanie, chociaż nie rości sobie prawa do wyczerpania tematu, nakreślić losy nowożytnych archiwów Gryfitów funkcjonujących na Pomorzu w XVI i pierwszych dekadach XVII w. Za podstawowe cele szczegółowe pracy uznano więc określenie liczby oraz miejsc posadowienia książęcych archiwów, ustalenie ich podległości, rodzaju wykonywanych zadań, liczebności personelu, warunków przechowywania akt oraz problemów z porządkowaniem i inwentaryzacją posiadanych materiałów. Ponadto $\mathrm{w}$ pracy zostały wspomniane archiwa prywatne Gryfitów, a także opisano próby stworzenia jednego centralnego książęcego archiwum u schyłku panowania Bogusława XIV. Wreszcie na koniec skrótowo nakreślono losy poksiążęcych akt po wymarciu dynastii Gryfitów. Prezentowana praca ma w dużej części charakter źródłowy, oparta jest bowiem na aktach z Archiwum Książąt Szczecińskich i Archiwum Książąt Wołogoskich.

${ }^{1}$ L. v. Medem, Das Königliche Provinzialarchiv zu Stettin, „Zeitschrift für Archivkunde, Diplomatik und Geschichte", Bd 2, Hf. 1835, s. 2-50.

${ }^{2}$ Zob. chociażby: Świadectwa historii Pomorza. Księstwo Pomorskie 1140-1648. Zeugnisse Pommerscher Geschichte. Herzogtum Pommern 1140-1648, red. K. Kozłowski, M. Schoebel, SzczecinGreifswald 1999; K. Kozłowski, Szczecin i jego archiwum. Tradycja i współczesność, [w:] Archiwa $i$ archiwiści $w$ dobie społeczeństwa informacyjnego. Pamiętnik IV Powszechnego Zjazdu Archiwistów Polskich, Szczecin 12-13 września 2002 r., t. 1, red. D. Nałęcz, Toruń 2002, s. 7-21; Mundus archii mundus memoriae. Archiwum Państwowe w Szczecinie 1945-2005, red. M. Frankel, Szczecin 2007, s. 10-12; Sąsiedzi w Europie. Księstwo Pomorskie i Królestwo Polskie (1000-1648). Nachbarn in Europa. Herzogtum pommern und Königreich Polen (1000-1648), oprac. M. Schoebel, J. Macholak, P. Gut, U. Rodig, Kraków-Szczecin-Greifswald 2012, s. 24-25.

3 J. Podralski, Przysięga szczecińskiego nadwornego archiwisty z 1613 roku, „Szczeciński Informator Archiwalny" 1996, nr 10, s. 9-11.

${ }^{4}$ Idem, Wstęp do inwentarza zespolu: Archiwum Książat Szczecińskich, Szczecin 1977.

${ }^{5}$ Idem, Archiwum Ksią̇ąt Szczecińskich. Przewodnik po zespole, cz.1 i 2, Szczecin 1991.

${ }^{6}$ A. Lazarek, Wstęp do inwentarza zespotu: Archiwum Ksiażąt Wołogoskich, Szczecin 2003. 


\section{Geneza nowożytnych archiwów książęcych i ich znaczenie}

Nowożytne archiwa książąt Gryfitów sięgają swymi początkami końca $\mathrm{XV}$ w. i wielkiej reformy księstwa pomorskiego przeprowadzonej przez Bogusława X. Wówczas to ukształtowały się organy centralne pomorskiej administracji (urzędy kanclerza, marszałka i rentmistrza krajowego - skarbnika). Urzędy te funkcjonujące w Szczecinie były obsługiwane przez książęcą kancelarię mieszczącą się na szczecińskim zamku. Z kancelarią ściśle związane było centralne archiwum księstwa pomorskiego. Owo archiwum, jedno dla całego Pomorza, funkcjonowało w Szczecinie dopóki żył książę Jerzy I (zmarł w maju 1531 r.). W 1532 r. doszło do podziału państwa pomiędzy spadkobierców Jerzego I, tj. książąt Filipa I (Księstwo Wołogoskie) i Barnima IX (Księstwo Szczecińskie). Podjęto wówczas decyzję o podziale zasobu szczecińskiego archiwum. Jeżeli chodzi o sprawy wewnętrzne, głównie gospodarcze, finansowe oraz stosunki z poddanymi, to zgromadzone w Szczecinie akta zostały rozdzielone zgodnie z przynależnością terytorialną między władców wołogoskiego i szczecińskiego. Gorzej było z archiwaliami odnoszącymi się do zwierzchności państwowej, a zwłaszcza polityki zagranicznej. W umowie podziałowej obaj książęta zobowiązali się do prowadzenia wspólnej polityki zagranicznej zarówno w stosunku do cesarza i księstw Rzeszy, jak i do państw leżących poza granicami cesarstwa (w tym do Polski). Chcąc dobrze funkcjonować, obie nowo utworzone kancelarie, tj. wołogoska i szczecińska, powinny posiadać komplet odpowiednich dokumentów. Ponieważ podział tej części materiałów archiwalnych był trudny do przeprowadzenia, a nie podjęto decyzji o ich masowym kopiowaniu, ostatecznie uznano, że zostaną one zdeponowane w Wołogoszczy. W tej sytuacji głównym archiwum państwa i dynastii miało stać się archiwum wołogoskie. Wbrew wcześniejszym ustaleniom w niedługim czasie oba archiwa, wołogoskie i szczecińskie, stały się wobec siebie równorzędne ${ }^{7}$. Natomiast od lat panowania księcia szczecińskiego Jana Fryderyka (lata 1569-1600), kiedy to w Szczecinie koncentrowała się cała pomorska polityka zagraniczna ${ }^{8}$, archiwum szczecińskie awansowało do roli głównego archiwum państwa i dynastii ${ }^{9}$. Wobec tego archiwum wołogoskie oprócz spraw tego księstwa przechowywało jedynie dość liczne odpisy akt dotyczących dynastii oraz wspólnej polityki zagranicznej. Dodatkowo w 1557 r. Gryfici objęli w całkowite władanie tzw. Księstwo Biskupie będące dawną domeną katolickich biskupów kamieńskich, a pierwszym świeckim biskupem został, wspo-

\footnotetext{
7 Świadectwa historii..., s. 10-11.

${ }^{8}$ Warto chociażby wspomnieć szczeciński kongres pokojowy (1570 r.), kończący I wojnę północną (lata 1563-1570), zob. choćby: S. Bodaniak, Kongres szczeciński na tle battyckiej polityki polskiej, Kraków 1929.

9 J. Podralski, Wstęp ..., s. 15-16.
} 
mniany już, książę Jan Fryderyk (lata 1557-1569) ${ }^{10}$. Ten fakt spowodował, że Gryfici przejęli również dawne archiwum biskupie.

W tej sytuacji w II połowie XVI w. Gryfici dzierżyli na Pomorzu trzy władztwa terytorialne: Księstwo Wołogoskie, Księstwo Szczecińskie i Księstwo Biskupie, które miały podobnie zbudowaną administrację, chociaż w wypadku terytorium biskupiego zdecydowanie skromniejszą. Pierwszym członem administracji każdego z władztw był tzw. zarząd dworu skupiający urzędników pracujących pod kierunkiem marszałka ${ }^{11}$, drugim była kancelaria nadzorowana przez kanclerza, której częścią do 1575 r. były sądy nadworne odpowiednio w Szczecinie, Wołogoszczy i Koszalinie ${ }^{12}$. Te ostatnie po 1575 r. usamodzielniły się, tworząc osobne (trzecie) organy administracji centralnej. Zatem po 1575 r. przy sądach nadwornych utworzono osobne, nieduże (2-3-osobowe) kancelarie współpracujące z radcami sądowymi. Jednocześnie przy kancelariach sądowych w księstwach wołogoskim, szczecińskim oraz biskupim powstały osobne książęce archiwa sądowe ${ }^{13}$. Czwartym urzędem centralnym były zarządy rentmistrzów krajowych (Landrentmistrza), w których pracowali radcy finansowi pobierający w każdym $\mathrm{z}$ księstw należne panującym podatki. Warto $\mathrm{w}$ tym miejscu podkreślić, że rentmistrzowie krajowi od podziału Pomorza w 1532 r. na odrębne władztwa mieli własne niewielkie kilkuosobowe kancelarie. Ich wytwory kancelaryjne po utracie bieżącej przydatności trafiały jednak do archiwów poszczególnych władztw. W tej sytuacji za archiwa książęce w II połowie XVI w. możemy uznać archiwum wołogoskie umiejscowione na zamku w Wołogoszczy, szczecińskie funkcjonujące na zamku w Szczecinie oraz biskupie umieszczone w rezydencji biskupów kamieńskich w Koszalinie. Obok nich w ksią-

${ }^{10}$ Przejęcie ziem biskupstwa przez Jana Fryderyka: Archiwum Państwowe w Szczecinie (dalej: AP w Szczecinie), 65/2/0 Archiwum Książąt Szczecińskich [1209] 1354-1831, sygn. 65/2/0/1.80/I/3359, s. $124-148$ i n.

${ }^{11}$ W zależności od księstwa, w którym służyli, rozróżniano wówczas marszałków na: szczecińskiego, wołogoskiego i biskupiego. Podobnie było z kanclerzami, rentmisztrzami czy sądami nadwornymi.

${ }^{12}$ W latach 70. XVI w. personel kancelarii szczecińskiej składał się z trzech sekretarzy, trzech kopistów oraz jednego sługi. Obsługiwali oni proces wytwarzania dokumentów zlecanych przez księcia lub kanclerza. Natomiast radcy książęcy, tworzący sąd nadworny, byli obsługiwani przez osobnego notariusza, sekretarza i kopistę tworzących osobną kancelarię: AP w Szczecinie, 65/3/0 Archiwum Książąt Wołogoskich [1401] 1532-1638 [1732], sygn. 65/3/0/29/403, k. 3-5, 8-9. Zob. także o sądzie nadwornym w Wołogoszczy: P. Gut, Sad Nadworny w Greifswaldzie w czasach szwedzkich i pruskich 1642-1849, „Szczeciński Informator Archiwalny” 2012, nr 21, s. $46-48$ (tam też podstawowa literatura przedmiotu).

${ }^{13}$ Sąd Nadworny w Szczecinie powstał w 1494 r. w czasach reformy pomorskiej administracji przeprowadzonej przez Bogusława X i obejmował swym działaniem całe Pomorze. Książęta wołogoscy dopiero ok. 1560 r. zdecydowali się powołać własny Sąd Nadworny w Wołogoszczy, którego okręgiem był obszar Księstwa Wołogoskiego. Natomiast sąd książęco-biskupi, działający od przełomu lat 50. i 60. XVI w., rozstrzygał sprawy z terenu Księstwa Biskupiego. 
żęcych siedzibach w Wołogoszczy, Szczecinie i Koszalinie funkcjonowały także archiwa sądów nadwornych.

Archiwa poszczególnych władztw terytorialnych posiadanych przez Gryfitów odgrywały niezwykle ważną, wręcz można rzec podstawową, rolę przy kreowaniu przez książąt zarówno polityki wewnętrznej, jak i zagranicznej. Zadania archiwów najwyraźniej określił w 1616 r. książę wołogoski Filip Juliusz. Według księcia archiwa winny przechowywać dokumenty własne (kopie dokumentów wydawanych przez kancelarię książęcą) i te otrzymane z innych państw pokazujące, zdaniem władcy, wzajemne stosunki między poszczególnymi dworami książęcymi. To właśnie archiwa w miarę potrzeby służyły dawnymi porozumieniami i traktatami pozwalającymi budować dalsze relacje z sąsiadami. Instytucje te były zatem postrzegane nie tylko jako miejsca składowania różnego rodzaju dokumentów, lecz również jako wspierające bezpośrednio bieżącą politykę zagraniczną i krajową władców ${ }^{14}$.

Praktyczne znaczenie archiwów w państwach Gryfitów i ich wzajemną współpracę pokazuje inicjatywa wspomnianego już księcia włogoskiego Filipa Juliusza, który w październiku 1616 r. poinformował księcia szczecińskiego Filipa II o tym, że zamierza podjąć negocjacje z Meklemburgią i Brandenburgią w sprawie ukrócenia rozboju (rozgromienie band rabusiów) na obszarach przygranicznych wymienionych państw. W tym celu, aby rozpocząc rozmowy, potrzebował odpisów dokumentów i umów zawieranych w tej sprawie z wymienionymi księstwami. Filip Juliusz kierował się w tym wypadku wskazówką wołogoskiego archiwisty Jacoba Seltenchtena, który poinformował księcia, że dokumenty odnoszące się do relacji z sąsiednimi księstwami (Brandenburgią, Meklemburgią) powinny być w Szczecinie jako głównym archiwum Gryfitów. W tej sytuacji Filip Juliusz prosił o skopiowanie niezbędnych mu dyplomów, które chciałby dostać do rąk własnych. Ostatecznie obaj Gryfici (Filip Juliusz i Filip II) przystąpili do koalicji przeciwko rabusiom i opierając się na posiadanych archiwaliach stworzyli wspólną deklarację w tej sprawie, a następnie przesłali ją na sąsiednie dwory ${ }^{15}$.

Książę wołogoski Filip Juliusz wyszedł również z inną ciekawą inicjatywą. Na podstawie dokumentów przechowywanych w podległych książętom archiwach chciał stworzyć tzw. Zapiski Pomorskie (Descriptionem Pomeranie) zawierające spisy miejscowego prawa, co w istocie miało stać się pomorskim kodeksem ${ }^{16}$. $\mathrm{Na}$ funkcjonujących wówczas dworach książęcych (wołogoskim, szczecińskim i biskupim) miano również świadomość, że zgromadzone w archiwach materiały mogą służyć do odtworzenia dziejów Gryfitów i ich państw, a przez to służyć budowaniu prestiżu pomorskiej dynastii w Europie. $\mathrm{Z}$ akt książęcych przy pisaniu

\footnotetext{
${ }^{14}$ AP w Szczecinie, sygn. 65/2/0/1.99/I/5194, s. 176-179.

15 Ibidem, s. 228-233, ostateczne zarządzenie w sprawie zachowaniu pokoju na drogach i walce $\mathrm{z}$ rabusiami: s. 279-289.

${ }^{16}$ Proponował nawet konsultacje w tej sprawie: ibidem, s. 167-191.
} 
kroniki pomorskiej korzystał np. opiekun archiwum wołogoskiego w czasach Filipa I Thomas Kantzow ${ }^{17}$.

Przytoczone fakty potwierdzają wyraźnie ważną rolę archiwów na Pomorzu nie tylko jako instytucji przechowujących stare dokumenty, ale także wspierających bieżącą politykę pomorskich władców oraz, co ważniejsze, posiadających, dostrzegany przez książąt, walor ponadczasowych skarbnic wiedzy o państwach Gryfitów.

\section{Personel archiwów książęcych}

Wszystkie wspomniane archiwa książęce, w tym i sądowe, były ściśle powiązane z kancelariami władztw terytorialnych, a poszczególni kanclerze byli zwierzchnikami zatrudnionych w nich archiwistów. Podległość archiwów kanclerzom była z kolei początkowo efektem decyzji książęcych, lecz wraz z osłabieniem ich władzy (od końca XVI w.) sprawę tę regulowały osobne uchwały pomorskich sejmików. Zazwyczaj bezpośrednim opiekunem każdego z archiwów był dobrze wykształcony urzędnik, najczęściej w randze radcy sądowego lub też sekretarza kancelarii. Na przykład za panowania księcia wołogoskiego Filipa I miejscowym archiwum, z nominacji władcy, opiekował się Thomas Kantzow, znany pomorski dziejopis. W czasach Filipa Juliusza (lata 1592-1625) podległość archiwum kanclerzowi księstwa wynikała już z ustaleń sejmiku wołogoskiego ${ }^{18}$. Sejmik ten określał także liczbę i hierarchię książęcych urzędników, wliczając w to archiwistów. W wykazie osób podległych kanclerzowi wołogoskiemu Danielowi Rungemu wymieniono szefa archiwum (Director) Eccard'a von Usedoma mającego do pomocy archiwistę (Verwalter) Adama Trampego. Szef archiwum pełnił równocześnie ważną funkcję wójta krajowego, stąd też to Trampe $\mathrm{w}$ rzeczywistości pracował $\mathrm{w}$ archiwum, będąc jednocześnie członkiem książęcego sądu nadwornego ${ }^{19}$.

Zadania i obowiązki książęcych archiwistów były szczegółowo opisywane w osobnych instrukcjach. Do naszych czasów zachowała się m.in. instrukcja z 1578 r. przeznaczona dla opiekuna archiwum sądu nadwornego w Szczecinie protonotariusza Johannesa Hechlera, służącego księciu Janowi Fryderykowi.

${ }^{17}$ Pomerania. Kronika pomorska z XVI wieku (Thomasa Kantzowa), thum. K. Gołda, przypisy i komentarze T. Białecki, K. Gołda, E. Rymar, t. 1 i 2, Szczecin 2005.

${ }^{18}$ Kanclerz odpowiadał za funkcjonowanie kancelarii, nadzorował sąd nadworny danego władztwa, stojąc na jego czele oraz wspierał księcia, w tym wypadku Filipa Juliusza, w polityce zagranicznej.

${ }^{19}$ AP w Szczecinie, sygn. 65/2/0/1.94/I/4639, s. 287, w poszycie wymieniano także radców i sekretarzy kancelarii książęcej: I/4639, s. 25, wreszcie wskazywano, że kanclerz jako przewodniczący sądu nadwornego, będzie miał do pomocy trzech asesorów, z których jeden już na stałe będzie archiwistą. Do wymienionego składu sądu nadwornego dochodził jeszcze protonotariusz, dwóch sekretarzy i dwóch kancelistów. Obsługę uzupełniali: registrator, urzędnik prowadzący finanse, egzekutor, pomocnik kancelaryjny i dwóch służących, ibidem, s. 32. 
Po pierwsze, Hachler miał trzymać wszystkie archiwalia w należytym porządku, a każdy nowy materiał kierowany do archiwum musiał być przez niego na bieżąco zapisywany w inwentarzu (w zasadzie w księdze wpływów). Po drugie, przechowywana korespondencja miała być układana alfabetycznie według pierwszych liter nazwisk nadawców i spisywana. Wreszcie po trzecie, szczególną uwagę opiekun archiwum miał zwracać na akta procesowe i rachunki. Dla tych materiałów powinien być prowadzony osobny rejestr. Oczywiście każdy opiekun archiwum sądowego miał pilnować, aby akta ani na chwilę nie pozostawały bez nadzoru. Po ich wykorzystaniu miały być one obowiązkowo zamykane w skrzyniach. Co jakiś czas akta sądowe podlegały skontrum sprawdzającemu ich kompletność. Opiekun archiwum, pełniący w istocie rolę archiwisty, był także zobowiązany do zachowania pełnej tajemnicy i w żadnym wypadku bez zgody kanclerza nie mógł robić kopii z oryginałów akt. Musiał również znać prawo oraz zarządzenia sądu ${ }^{20}$. Trzeba na koniec dodać, że archiwum Sądu Nadwornego Księstwa Szczecińskiego było ściśle powiązane z kancelarią sądową, a protonotariusz Johannes Hechler pełnił podwójną funkcję opiekuna archiwum i szefa kancelarii ${ }^{21}$.

Podobne obowiązki zostały nałożone w 1613 r. na archiwistę archiwum władztwa szczecińskiego Jacoba Frosta, służącego Filipowi II. Musiał on przede wszystkim dbać o porządek w archiwum, a zwłaszcza pilnować dokumentów pergaminowych, które powinny być przechowywane w odpowiednio zabezpieczonych skrzyniach, podczas gdy akta można było składować w szafach. Jego zadaniem było wreszcie prowadzanie ewidencji dla przechowywanych archiwaliów. Poza zapoznaniem się z książęcą instrukcją każdy pomorski archiwista składał, podobnie jak inni urzędnicy, przysięgę swojemu władcy. Przykładem takiego dokumentu jest przysięga wspomnianego już Jacoba Frosta, złożona w sierpniu 1613 r. przed obliczem księcia Filipa II $^{22}$. Frost zobowiązywał się w niej pilnie dbać o przechowywane w archiwum akta, dokumenty i listy, utrzymywać porządek w pomieszczeniach archiwalnych oraz prowadzić rejestr wszystkich archiwaliów, aby nie zaginęły i były zawsze dostępne. Jego obowiązkiem było także pełne posłuszeństwo kanclerzowi i wykonywanie jego poleceń. Każdy książęcy archiwista, w tym oczywiście i Frost, przysięgał, że nie zdradzi tajemnic i sekretów zapisanych na kartach dokumentów znajdujących się w archiwum. Zakazywano wreszcie archiwiście przyjmowania jakichkolwiek

\footnotetext{
${ }^{20}$ AP w Szczecinie, sygn. 65/3/0/29/403, k. 8-14, 65/3/0/29/416, k. 34-36.

${ }^{21} \mathrm{Na}$ utrzymanie każdej z pomorskich kancelarii przeznaczone były środki finansowe oraz naturalia, np.: w zbożu, zwierzętach czy piwie pochodzące z dóbr książęcych. Np. kancelaria szczecińska w 1569 r. liczyła kanclerza, trzech sekretarzy, trzech pisarzy i służącego: AP w Szczecinie, sygn. 65/3/0/29/416, k. 10. Taki sam personel kancelaria szczecińska miała w 1575 r.: ibidem, k. 29-31. Obowiązki sekretarzy i pisarzy: ibidem, k. 13-16, oraz taksa kanclerska: ibidem, k. $18-21$.

${ }^{22}$ J. Podralski, Przysięga ..., s. 10-11.
} 
korzyści od osób trzecich. Po śmierci Filipa II (1618 r.) Frost pełnił funkcję nadwornego archiwisty także na dworach Franciszka I, a następnie Bogusława XIV. Wiadomo, że w 1630 r. pobierał 100 talarów wynagrodzenia rocznie oraz dodatkowo otrzymywał 30 talarów i cztery grosze na ubranie, a także 173 talary ekwiwalentu na dodatkowe wydatki, w tym m.in. na mieszkanie (Kostgeld). Ponadto książęcemu archiwiście przysługiwał deputat w naturze obejmujący: 1 winspel żyta ${ }^{23}$, 1 winspel jęczmienia, 1 woła, 3 barany, 2 świnie, 2 indyki i 3 fady $^{24}$ drewna opałowego. Wreszcie co roku archiwista otrzymywał 10 talarów i 32 grosze z przeznaczeniem na zakup wina ${ }^{25}$. Wobec tego, że z biegiem lat Frost podupadał na zdrowiu i siłach, Bogusław XIV postanowił w 1635 r. powołać nowego archiwistę. Zobowiązanie prowadzenia archiwum w ciężkich czasach przyjął w styczniu 1635 r. Walentin Curckmas. Jego obowiązki w stosunku do poprzednika nie tylko pozostały takie same, ale nawet zwiększyły się wobec planów zwiezienia wszystkich archiwaliów książęcych do Szczecina. Natomiast wynagrodzenie ostatniego książęcego archiwisty było, ze względu na toczącą się wojnę, zdecydowanie skromniejsze. Otrzymywał on roczną zapłatę w wysokości 50 talarów, 20-talarowy dodatek na ubranie oraz 20 talarów na mieszkanie. Z licznych wcześniejszych naturaliów przysługiwały mu tylko dwa fady drewna opałowego. Mógł się za to stołować przy książęcym stole ${ }^{26}$.

$\mathrm{Z}$ tych dość skromnie zachowanych informacji jednoznacznie wynika, że personel archiwów książęcych (wołogoskiego, szczecińskiego i biskupiego) był najczęściej bardzo szczupły i każde z archiwów miało jednego opiekuna - archiwistę. Nieco odmiennie sytuacja wyglądała w książęcych archiwach sądowych (wołogoskim, szczecińskim i biskupim), gdzie z reguły opiekun archiwum był równocześnie szefem kancelarii sądowej.

\section{Zasoby archiwów książęcych, ich przechowywanie i inwentaryzacja}

Wszystkie wymienione archiwa umiejscowione w głównych siedzibach książęcych były pilnie strzeżone. Przykładowo archiwum wołogoskiej linii książęcej umieszczono po $1532 \mathrm{r}$. w wieży wołogoskiego zamku ${ }^{27}$ rozbudowywanego od 1496 r. przez Bogusława X. Posadowienia archiwum nie zmieniła ani przebudowa rezydencji prowadzona przez Filipa I, ani też jej odbudowa ${ }^{28}$ w renesansowym kształcie w latach 1558-1563. Archiwum nadal znajdowało

${ }^{23}$ Winspel, to miara pojemności ciał sypkich używana na Pomorzu do mierzenia zboża równa ok. 1313 litrom.

${ }^{24} \mathrm{Fad}$, to miara pojemności w przypadku drewna opałowego odpowiadająca mniej więcej 1 furze drewna, czyli ok. $2 \mathrm{~m}^{3}$.

${ }^{25}$ AP w Szczecinie, sygn. 65/2/0/1.79///3160, s. 3, 16, 28, 53.

${ }^{26}$ Ibidem, sygn. 65/2/0/1.79/I/3152, s. 49-51.

27 L. v. Medem, op.cit., s. 9.

${ }^{28}$ Odbudowa zamku w duchu renesansu wynikała z jego częściowego zniszczenia przez pożar w $1557 \mathrm{r}$. 
się w wieży, a przed ewentualnym włamaniem zabezpieczały je ciężkie obite metalem drzwi z odpowiednim zamkiem. Były one zawsze opieczętowane, a wejścia do archiwum dokonywano komisyjnie. Pierwotnie archiwum obejmowało jedno duże, ciemnie pomieszczenie, co mocno utrudniało korzystanie ze zgromadzonych $\mathrm{w}$ nim akt. $\mathrm{Z}$ zachowanych informacji wiadomo, że w 1572 r. archiwum składało się już z dwóch widnych pomieszczeń. Same archiwalia były przechowywane bądź w skrzyniach (głównie dokumenty pergaminowe), bądź też w szafach (akta) ${ }^{29}$. Nie wiemy natomiast, w jakim miejscu funkcjonowało archiwum szczecińskie przed przebudową książęcej rezydencji. Najprawdopodobniej umieszczono je w tzw. kamiennym domu wzniesionym w 1345 r. przez Barnima III. Dopiero renesansowa przebudowa szczecińskiej rezydencji, przypadająca na lata 1575-1577, zmieniła diametralnie sytuację. Wszystkie urzędy książęce zostały wówczas umieszczone na parterze wschodniego skrzydła zamku. Tam też przeniesiono szczecińskie archiwa, w tym sądowe, którym przydzielono odpowiednie pomieszczenia wyposażone w skrzynie na dokumenty i szafy na akta. Podobnie jak w Wołogoszczy, tak i w Szczecinie archiwa zabezpieczono masywnymi drzwiami, a dostęp do nich był ograniczony. Trzecie z książęcych archiwów, najmniej znane, tzw. biskupie, znajdowało się, przynajmniej od lat 80 . XIV w., na zamku biskupów kamieńskich w Karlinie. Tam też początkowo umiejscowiono sąd nadworny księstwa oraz archiwum sądowe ${ }^{30}$. W II połowie lat 70. XVI w. oba archiwa (władztwa i sądowe) przewieziono do nowej rezydencji biskupiej w Koszalinie $^{31}$. Był to przebudowany w latach 1568-1575 przez pierwszego świeckiego biskupa kamieńskiego księcia Jana Fryderyka dawny klasztor koszalińskich cysterek. Najprawdopodobniej archiwa biskupie zostały umieszczone na parterze głównego skrzydła rezydencji obok kancelarii ${ }^{32}$. Jak można przypuszczać, zajmowały one osobne, dobrze zabezpieczone pomieszczenia odpowiednio wyposażone w skrzynie i szafy.

Trzeba podkreślić, że w każdym z książęcych archiwów starano się dbać o porządek oraz na bieżąco inwentaryzować napływające dokumenty i akta. W archiwum wołogoskim za panowania Filipa I w 1538 r. wykonano pierwszą znaną inwentaryzację zasobu aktowego, a w 1544 r. spisano wszystkie dokumenty pergaminowe. Dokonał tego ówczesny opiekun archiwum wołogoskiego Thomas Kantzow. Wspomnianą inwentaryzację zasobu przeprowadzano z kilku powodów. Po pierwsze, chodziło o dokładną rejestrację archiwa-

\footnotetext{
${ }^{29}$ L. v. Medem, op.cit., s. 26-29, oraz A. Łazarek, op.cit., s. 11.

${ }^{30}$ Hofgericht des Stifs Cammin: AP w Szczecinie, sygn. 65/2/0/1.80/I/3359, s. 3 i n.

${ }^{31}$ Od przejęcia władztwa biskupiego przez Gryfitów w 1557 r. do II połowy 1. 70. XVI w. archiwum biskupie znajdowało się na zamku biskupim w Karlinie.

${ }^{32}$ R. Gaziński, W nowożytnym państwie pomorskim (1523-1653), [w:] Dzieje Koszalina, t. 1, do 1945 r., red. R. Gaziński, E. Włodarczyk, Koszalin 2016, s. 122-123, oraz E. Gwiazdowska, Miasto w źródtach ikonograficznych, [w:] ibidem, s. 352-353.
} 
liów przywiezionych świeżo ze Szczecina. Po drugie, książę i jego otoczenie chciało mieć pełną informację o posiadanym zasobie archiwalnym. Wreszcie po trzecie, inwentaryzacja archiwaliów ułatwiała pracę Kantzowowi nad planowanymi dziejami Pomorza. Kolejne pełne skontrum zasobu wołogoskiego archiwum przeprowadzono w 1572 r., a repertorium sporządził ówczesny kanclerz wołogoski Joachim Bekhan. Spis obejmował cały zasób, na który składały się: dokumenty pergaminowe, odpisy dokumentów, korespondencja, księgi i akta ${ }^{33}$. Trzeba podkreślić, że wśród spisanych archiwaliów dużą grupę stanowiły dokumenty i księgi sekularyzowanych klasztorów z obszaru Księstwa Wołogoskiego. Ostatecznie z repertorium wynikało, że w 1572 r. archiwum posiadało łącznie 1934 j.a., które były podzielone na 39 niewielkich grup rzeczowych. Większość archiwaliów przechowywano w szafach, a ostatnie siedem grup było złożonych w skrzyniach. W następnych latach repertorium Bekhan'a było uzupełniane o kolejne dopływy akt. Wiadomo, że do 1575 r. dopisano 159 nowych jednostek. Trzecie, znane dzisiaj wielkie skontrum zasobu wołogoskiego archiwum, przeprowadzono w $1603 \mathrm{r}$. Autorem nowego repertorium był ówczesny opiekun archiwum Mikołaj Klemptzen. Przechowywane wówczas archiwalia liczyły razem 2361 j.a. tworzących 43 grupy rzeczowe. Natomiast pierwszy znany spis archiwaliów przechowywanych w Szczecinie został przeprowadzony w 1578 r. pod nadzorem kanclerza szczecińskiego Jacoba v. Kleista ${ }^{34}$. Cały zasób archiwum tworzyło wówczas 51 niedużych grup rzeczowych liczących około 3 tys. j.a. Wraz z biegiem lat wzrastała liczba napływających do archiwum akt, co zmusiło władze kanclerskie w 1610 r. do przeprowadzenia drugiego kompleksowego skontrum. Zasób szczecińskiego archiwum liczył wówczas około 5 tys. j.a., podzielonych na 88 grup rzeczowych. Przed 1638 r. nie zachowały się żadne informacje o skontrach archiwów biskupich (władztwa i sądowego). Wiadomo jedynie, że w II połowie lat 70 . XVI w. w trakcie przeprowadzki z Karlina do Koszalina spisano częściowo biskupie archiwum sądowe, którym opiekował się ówcześnie protonotariusz Joachim Schorzow, będący również szefem kancelarii sądowej książąt biskupów. Naliczono wówczas około 60 j.a. akt procesowych i 29 listów z I połowy XVI w. ${ }^{35}$ Do tego należałoby jeszcze dodać depozyt wójta księstwa biskupiego Asmusa Podewilsa, przekazany do archiwum w 1566 r., a liczący około 40 listó $^{36}$. Wspomniane archiwalia były przechowywane w Karlinie w skrzyniach. Wkrótce okazało się, że w II połowie lat 70. XVI w. nie wszystkie archiwalia zostały konsekwentnie wywiezione do Koszalina. W Karlinie pozostała skrzynia z 330 dokumentami z lat 1297-1542. Spisał je w sierpniu 1581 r. na polecenie księcia biskupa Kazimierza VI sekretarz kancelarii sądowej Kasper

\footnotetext{
${ }^{33}$ A. Lazarek, op.cit., s. 12.

${ }^{34}$ Sasiedzi w Europie..., s. 24.

${ }^{35}$ AP w Szczecinie, sygn. 65/2/0/1.80/I/3359, s. 3-21.

${ }^{36}$ Ibidem, s. 22-26.
} 
Funck. W 1582 r. na wyraźne żądanie Kazimierza VI skrzynię z dokumentami przetransportowano do Koszalina ${ }^{37}$.

Na koniec warto dodać, że w trakcie drugiej inwentaryzacji szczecińskiego zasobu (1610 r.) panujący ówcześnie książęta, wołogoski Filip Juliusz i szczeciński Filip II, postanowili wymienić archiwalia niepasujące do zasobów ich archiwów ze względu na przynależność terytorialną. Pierwszym etapem planowanej szerzej wymiany było przekazanie w $1610 \mathrm{r}$. z archiwum wołogoskiego do szczecińskiego akt dotyczących Szczecina oraz licznych układów, jakie książęta szczecińscy zawierali z tym miastem. Miał być to pierwszy krok do generalnego sprofilowania zasobów obu archiwów. Dalsze rozwiązywanie tego problemu powierzono kanclerzom obu księstw, którzy mieli ustalić, jakie akta lub ich odpisy powinny trafić z Wołogoszczy do Szczecina i odwrotnie. Należało w tym celu stworzyć wspólną specyfikację materiałów, które podlegałyby następnie wymienianie lub skopiowaniu ${ }^{38}$. Ostatecznie planowana akcja, mimo dość intensywnej wymieniany korespondencji, nie doszła do skutku.

Na podstawie powyższych rozważań można stwierdzić, że mimo licznych trudności władze kanclerskie i personel archiwalny starały się utrzymywać należyty porządek w podległych sobie archiwach. Dbano szczególnie o ewidencję przechowywanych archiwaliów. Efektem wspomnianych dążeń były dość często przeprowadzane skontra zasobów archiwalnych, mające na celu rejestrację stanu posiadania poszczególnych archiwów.

\section{Archiwa prywatne Gryfitów}

Osobnym problemem, który należy poruszyć są prywatne archiwa Gryfitów przechowywane najczęściej w książęcych apartamentach. Na dość liczne ślady o nich można się natknąć, analizując pośmiertne inwentarze książęcych ruchomości. Warto tu podkreślić, że po zgonie każdego z książąt powoływano specjalną komisję, która spisywała wszystkie ruchomości, na jakie natrafiono w książęcych apartamentach, w tym książki i „papiery”. Jak można przypuszczać, większość owych „papierów” nie podlegała podziałowi między żyjących członków dynastii, lecz była przekazywana do odpowiednich archiwów ${ }^{39}$.

Przykładowo, w prywatnych apartamentach Barnima IX Starego na zamku w Oderburgu (tzw. zamku odrzańskim) po jego śmierci w 1573 r. natra-

${ }^{37}$ Ibidem, s. 29-31, 35-122.

${ }^{38}$ Ibidem, sygn. 65/3/0/29/525, k. 33-34, 36, 42, 45, 49-50, 54-71.

${ }^{39}$ Przypuszczenie to wydaje się być zasadnym wobec zawartości treściowej dzisiejszych zespołów - Archiwum Książąt Szczecińskich i Archiwum Książąt Wołogoskich: Archiwum Państwowe w Szczecinie. Przewodnik po zasobie archiwalnym. Akta do 1945 r., oprac. R. Gaziński, P. Gut, M. Szukała, Warszawa-Szczecin 2002, s. 19-39; J. Podralski, Archiwum ..., s. 595, oraz wstępy do inwentarzy: J. Podralski, Wstęp ..., oraz A. Łazarek, op.cit., (oba inwentarze w AP w Szczecinie). 
fiono nie tylko na liczną korespondencję rodzinną, ale także na pergaminowe dokumenty w dużej mierze proweniencji kościelnej oraz na sporą liczbę suplik składanych księciu przez poddanych w różnych sprawach ${ }^{40}$. Książęce „papiery” były złożone w dwóch osobnych skrzyniach, z których jedna zawierała wyłącznie korespondencję. Gdy w 1560 r. zmarł na zamku w Wołogoszczy Filip I, komisarze spisujący ruchomości w jego komnatach natrafili obok licznych książek na tzw. papiery osobiste. Była to przede wszystkim oficjalna korespondencja księcia z władcami szczecińskimi ${ }^{41}$. Oprócz tego Filip I przechowywał korespondencję z najbliższą rodziną oraz z cesarzem. Ponadto w jego prywatnym archiwum były przywileje oraz księgi sekularyzowanych klasztorów zarówno z terenu księstwa, jak i z samej Wołogoszczy. Znajdowały się tam również rejestry celne oraz spisy wołogoskich urzędników. Książęce prywatne archiwum Filipa I było złożone w kilku skrzyniach $^{42}$. Podobne archiwum jak Filip I posiadał także książę szczeciński Jan Fryderyk. Po jego śmierci w 1600 r. w książęcych apartamentach szczecińskiego zamku znaleziono prywatną korespondencję z członkami rodziny Gryfitów złożoną w kilku skrzyniach. Z korespondencją przemieszane były dokumenty o charakterze dyplomatycznym, przede wszystkim dotyczące stosunków z elektorami brandenburskimi oraz z cesarzem. Sporą część „papierów osobistych" Jana Fryderyka stanowiły, niespłacone najczęściej, książęce rachunki ${ }^{43}$. Głównie z korespondencji oraz niespłaconych rachunków składało się prywatne archiwum Barnima X, zmarłego w 1603 r. w Szczeci$n \mathrm{e}^{44}$. Korespondencja przeważała także w prywatnym archiwum Bogusława XIII, zmarłego w 1606 r. Oprócz niej spisujący zarejestrowali wiele akt synodalnych, zarządzenia księcia Jana Fryderyka, testament samego Bogusława XIII, książęce rachunki i obligacje, wreszcie akta dotyczące miast Barth, Franzburg i Wołogoszcz. Część korespondencji oraz akt była już spisana, co ułatwiało księciu odszukiwanie potrzebnych materiałów ${ }^{45}$.

Obok archiwów władztw i sądowych poszczególni książęta z dynastii Gryfitów gromadzili w swoich apartamentach korespondencję rodzinną i dyplomatyczną. Przechowywali także akta o proweniencji państwowej niezbędne im do bieżącego sprawowania władzy. Czasami trafiały się tam również średniowieczne księgi i dyplomy, najczęściej pochodzenia kościelnego. Wspomniane archiwa prywatne były po śmierci książąt włączane do archiwów poszczególnych władztw.

\footnotetext{
${ }^{40}$ Szczegółowy spis posiadanych przez Barnima IX Starego dokumentów: AP w Szczecinie, sygn. 65/2/0/1.50/I/1902, s. 261-273, 275-287, 293-312.

${ }^{41}$ Ibidem, sygn. 65/2/0/1.51/I/1917, s. 34-41, oraz sygn. 65/2/0/1.51/I/1918, s. 36-44.

42 Ibidem, s. 137-138.

${ }^{43}$ Ibidem, sygn. 65/2/0/1.51/I/1, s. 2-3.

${ }^{44}$ Ibidem, sygn. 65/2/0/1.51/I/1963, s. 14 , sygn. 65/2/0/1.51/I/1965, s. 50.

${ }^{45}$ Ibidem, sygn. 65/2/0/1.51/I/1975, s. 3-6.
} 


\section{Centralizacja archiwaliów książęcych w czasach Bogusława XIV}

Po śmierci w 1626 r. księcia Filipa Juliusza, ostatniego przedstawiciela wołogoskiej linii Gryfitów na dworze szczecińskim, podjęto decyzję o przeniesieniu archiwaliów z Wołogoszczy do Szczecina, co motywowano przede wszystkim zagrożeniem zewnętrznym Pomorza. W pierwszej kolejności wiosną 1628 r. do Szczecina przewieziono część dokumentów pergaminowych. Uczyniono to po tym, jak wołogoskie archiwum zostało (wczesną wiosną 1628 r.) częściowo splądrowane przez okupujące Wołogoszcz wojska cesarskie. Zarówno dokumenty, jak i akta zostały wówczas wyrzucone ze skrzyń i szaf oraz przemieszane, a niektóre z nich, zwłaszcza dokumenty pergaminowe, zabrano. Ledwie zebrano rozproszone archiwalia, gdy dość niespodziewanie Wołogoszcz została na krótko na początku sierpnia 1628 r. zajęta przez Duńczyków. Wojska duńskie dokonały rabunku i poważnego zniszczenia zamku, a świeżo ułożony zasób wołogoskiego archiwum został ponownie rozproszony. Część akt uległa wówczas zniszczeniu. W tej sytuacji na początku $1629 \mathrm{r}$. Bogusław XIV zarządził inwentaryzację wołogoskiego archiwum, aby już uporządkowane akta przewieźć do Szczecina ${ }^{46}$. Wykonanie prac porządkowych było zasługą radcy Alberta Wackenniza, który rozpoczął je jeszcze pod koniec $1628 \mathrm{r}$. Prace te kontynuował następnie superintendent doktor Bartoldo Krakenitzen. Ten ostatni sporządził w lipcu 1629 r. relację z procesu porządkowania wołogoskich archiwaliów ${ }^{47}$. Jesienią 1629 r. próbowano przewieźć książęce akta do mniej zagrożonego od Wołogoszczy Loitz, ale ostatecznie uznano, że transport archiwaliów będzie zbyt niebezpieczny. Mimo to w niewyjaśnionych do końca okolicznościach niewielką część archiwaliów z Wołogoszczy przetransportowano pod koniec 1629 r. do Wkryujścia (Uckermünde). Wobec realnej groźby stopniowego rozproszenia i zniszczenia całego wołogoskiego archiwum Bogusław XIV próbował przyspieszyć jego przewóz do Szczecina. Sprzeciwily się temu w sposób zdecydowany stany Księstwa Wołogoskiego, wskazując na niemożność znalezienia w ogołoconym księstwie środków niezbędnych do sfinansowania bezpiecznego transportu archiwaliów.

W lutym 1631 r. z inicjatywy wołogoskiego kanclerza Nicolausa v. Ahima podjęto kolejną inwentaryzację archiwum ${ }^{48}$. Natomiast w 1632 r. Friedrich Bohlen spowodował przewiezienie niewielkiej części wołogoskich archiwaliów do Greifswaldu, gdzie złożono je na ratuszu ${ }^{49}$. Pozostałe w Wołogoszczy akta miano jak najszybciej przetransportować do Szczecina. Życzył sobie tego Bogusław XIV, ponaglając wołogoskich urzędników pismami z grudnia 1632 r., a następnie z marca 1633 r.. Ostatni książę pomorski pragnął zabezpieczyć na szczecińskim

${ }^{46}$ Ibidem, sygn. 65/3/0/29/526, pnobl.

47 Ibidem.

${ }^{48}$ Zinwentaryzowano wówczas akta złożone w czterech szafach dębowych dobrze zamykanych. Faktycznie spisu dokonał pisarz Petro: ibidem, AP w Szczecinie, sygn. 65/3/0/29/525, pnobl.

${ }^{49}$ A. Łazarek, op.cit., s. 13. 
zamku wszystkie archiwalia należące do Gryfitów. Do momentu przewiezienia wołogoskiego archiwum do Szczecina książę wyznaczył na jego opiekuna radcę książęcego Sylwestra Braunschweiga ${ }^{50}$. Transport akt miały zorganizować stany Księstwa Wołogoskiego, które wyraźnie sabotowały polecenia Bogusława XIV.

Zdecydowanie mniej uwagi Bogusław XIV poświęcał archiwum biskupiemu w Koszalinie. To raczej miejscowym elitom bardziej zależało na zabezpieczeniu koszalińskich archiwaliów. Już w październiku 1623 r. duchowieństwo biskupstwa kamieńskiego złożyło postulat, aby wobec narastającego zagrożenia zewnętrznego przenieść biskupie archiwum do Kołobrzegu. Planowano je umieścić pod opiekę kapituły kołobrzeskiej. Do Kołobrzegu wraz z archiwum miałaby się także przenieść kancelaria biskupia oraz sam kanclerz ${ }^{51}$. Sprawa ta nie spotkała się z przychylnością Bogusława XIV, który nie zezwolił ani na transport akt, ani też na przeprowadzkę kancelarii. Wobec tego we wrześniu 1626 r. sejmik Księstwa Biskupiego jeszcze raz zaapelował do księcia, aby pozwolił na zmianę lokalizacji kancelarii i archiwum, wskazując na Kołobrzeg jako na docelowe miejsce funkcjonowania obu powiązanych ze sobą instytucji. W październiku 1626 r. kolejną suplikę w tej sprawie przedłożyło szczecińskiemu władcy duchowieństwo księstwa biskupiego oraz biskupi kanclerz, proponując niezwłoczne przeniesienie kancelarii i archiwum z Koszalina do Kołobrzegu. Argumentowano to faktem, że z biegiem lat niebezpieczeństwo zewnętrzne wcale nie zmalało, lecz wydatnie wzrosło ${ }^{52}$. Poza zagrożeniem wskazywano również na trudne warunki pracy w Koszalinie, a przede wszystkim na brak odpowiednich mieszkań dla urzędników i zły stan koszalińskiej siedziby biskupiej, wymagającej pilnego remontu. Podkreślano wreszcie, że dobre zabezpieczenie (w Kołobrzegu) archiwum i kancelarii leży zarówno w interesie stanów księstwa biskupiego, jak i samego księcia. W styczniu 1627 r. złożono następną prośbę o przeniesienie kancelarii i archiwum biskupiego do Kołobrzegu ${ }^{53}$. Bogusław XIV na wspomniane petycje odpowiedział dopiero we wrześniu 1627 r., nie zgadzając się z argumentacją stanów, co spowodowało, że archiwum biskupie pozostało w Koszalinie ${ }^{54}$.

Dopiero w 1635 r., kiedy podejmowano już dramatyczne próby zgromadzenia w Szczecinie wszystkich książęcych archiwaliów, Bogusław XIV, za radą stanów księstwa biskupiego, podjął wreszcie decyzję (czerwiec 1635 r.), aby w Szczecinie zabezpieczyć również akta koszalińskiego archiwum biskupiego. W pierwszym rzędzie miało to dotyczyć oryginalnych dokumentów (głównie pergaminowych), w miejsce których w archiwum mia-

\footnotetext{
${ }^{50}$ AP w Szczecinie, sygn. 65/3/0/29/526, k. 7-8.

${ }^{51}$ Ibidem, sygn. 65/2/0/1.84/I/3886, s. 3-8.

52 Ibidem, s. 9.

${ }^{53}$ Ibidem, s. 10-12, 14-17, trzeba w tym miejscu dodać, że o planach przeniesienia archiwum i kancelarii do Kołobrzegu, gdzie były lepsze warunki bytowe dla urzędników, dyskutowano już na sejmiku księstwa biskupiego w $1604 \mathrm{r}$.

${ }^{54}$ Ibidem, s. 19-21.
} 
no pozostawiać uwierzytelnione odpisy ${ }^{55}$. Do śmierci Bogusława XIV tylko niewielką część koszalińskich archiwaliów przywiózł na szczeciński zamek Josue Engelbrecht.

Wymarcie linii wołogoskiej Gryfitów, zagrożenie zewnętrzne Pomorza, a następnie objęcie jego terytorium wojną trzydziestoletnią spowodowało podjęcie przez Bogusława XIV decyzji o zwiezieniu wszystkich książęcych archiwaliów do Szczecina. Jednak do końca życia ostatniego Gryfity na szczeciński zamek przywieziono jedynie część dokumentów pergaminowych z Wołogoszczy (1628 r.) oraz z Koszalina (1635 r.). Brak środków na transport, opór stanów Księstwa Wołogoskiego mocno ograniczyły plany książęce, stąd też w chwili śmierci Bogusława XIV (1637 r.) archiwalia książęce nadal pozostawały w rozproszeniu.

\section{Losy archiwaliów książęcych po wymarciu dynastii Gryfitów}

W momencie śmierci Bogusława XIV (marzec 1637 r.) książęce archiwalia były nadal rozproszone i znajdowały się w Szczecinie, Wołogoszczy i Koszalinie. Latem 1637 r. atak wojsk cesarskich na Pomorze poważnie zagroził archiwaliom koszalińskim. Armia szwedzka dowodzona przez gen. Johanna Bannera $\mathrm{z}$ trudem odparła uderzenie cesarskie, a walki toczyły się również w okolicach Koszalina. W tej sytuacji w trybie pilnym wywieziono archiwum biskupie z Koszalina, rozmieszczając jego zasób w kilku miejscach (Kołobrzeg, Karlino, Darłowo). Ewakuacją archiwaliów kierował ówczesny opiekun archiwum protonotariusz Matthias Engelbrecht. Gdy zagrożenie minęło, archiwalia ponownie zwieziono do Koszalina. Wiosną 1638 r. dotychczasowy opiekun archiwum zmarł, a na jego miejsce powołano Martina Pamponio. Został on w kancelarii biskupiej protonotariuszem i jednocześnie opiekunem archiwum ${ }^{56}$. To właśnie Martin Pamponio w czerwcu 1638 r. na zlecenie Paula Damitza, namiestnika księstwa biskupiego, Nicolasa Podewilsa, wójta księstwa biskupiego, oraz Joachima Nauinsa, kanclerza księstwa biskupiego, dokonał inwentaryzacji archiwum. Wraz z inwentaryzacją uporządkowano akta, które utworzyły 21 grup rzeczowych różnej wielkości liczących około 650 j.a. ${ }^{57} \mathrm{~W} 1639$ r. władze szwedzkie ściągnęły ostatecznie archiwa książęce do Szczecina. W pierwszej kolejności przywieziono na szczeciński zamek archiwum książąt wołogoskich, a następnie biskupów kamieńskich. Zatem zgromadzone w Szczecinie przez Szwedów archiwalia poksiążęce obejmowały dawne archiwum książąt szczecińskich, archiwum książąt wołogoskich oraz archiwum biskupów kamieńskich. Do tego należy

\footnotetext{
55 Ibidem, s. 23-25.

${ }^{56}$ AP w Szczecinie, 65/16/0 Rękopisy i spuścizny 1321-1946, sygn. 65/16/0/61/644, s. 2-4.

${ }^{57}$ Ibidem, 644, s. 4-7, a szczegółowy opis zawartości: s. 8-123.
} 
jeszcze dodać zgromadzenie w Szczecinie większości akt dawnych książęcych archiwów sądowych ${ }^{58}$.

W 1642 r. Szwedzi przeprowadzili inwentaryzację i porządkowanie wszystkich akt poksiążęcych. Do Archiwum Książąt Szczecińskich włączono wówczas jako osobną część archiwum biskupie. Razem oba archiwa zostały podzielone na 134 grupy rzeczowe różnej wielkości, przy czym dość szczegółowe informacje zachowały się dla grup rzeczowych od Titulusu 77 w górę 59 . Akta tworzące grupy rzeczowe od numeru 77 do 134 zawierały archiwalia dotyczące m.in.: hołdów lennych, spraw monetarnych, relacji z Sądem Kameralnym Rzeszy i Księstwem Biskupim, a także odnoszące się do: sporów granicznych, miast pomorskich, kapituły kamieńskiej, konsystorza ewangelickiego, superintendentów i religii na Pomorzu, pedagogium książęcego, finansów Księstwa Szczecińskiego, sejmików krajowych, spraw wojskowych, umów i donacji książęcych, pomorskich rodów szlacheckich wreszcie spraw sądowych ${ }^{60}$. Między poszczególnymi grupami rzeczowymi istniała duża rozbieżność. Najliczniejsza z nich (Tit. 101) liczyła 286 j.a., dotyczących stosunków z poddanymi, zwłaszcza ze szlachtą zamkową ${ }^{61}$, a najmniejsze (Tit. 91 i 130) miały po 12 j.a., i odnosiły się do miasta Greifswaldu oraz stosunków Szczecina z innymi miastami pomorskimi ${ }^{62}$. W sumie liczba akt wymienionych w analizowanym inwentarzu (Tit. 77-134) wynosiła około 4300 j.a. Wobec tego szacunkowo całe archiwum pozostałe po linii szczecińskiej Gryfitów, wraz z dołączonym do niego archiwum biskupim liczącym około 650 j.a., można w 1642 r. oszacować na około 9 tys. j.a. ${ }^{63}$

${ }^{58}$ T. Kozłowski, Szczecin i jego..., s. 9, oraz idem, Refleksje na sześćdziesięciolecie Archiwum Państwowego w Szczecinie. Tradycja - problemy - ludzie, [w:] Mundus archii..., s. 11.

${ }_{59}$ Zob.: AP w Szczecinie, sygn. 65/2/0/3.18/III/424, s. 3-243, oraz sygn. 65/2/0/3.18/III/425, s. 1-622, gdzie zawartość od Titulusu 81 do Titulusu 99, lecz już z aktami narosłymi w II połowie XVII i XVIII w.

${ }^{60}$ Patrząc na akta Książąt Szczecińskich, z dzisiejszego punktu widzenia, wymienione w analizowanym inwentarzu titulusy w przeważającej części dotyczyły spraw wewnętrznych. Dzisiaj tworzą one Pars II zespołu Archiwum Książąt Szczecińskich. Jak można przypuszczać, titulusy wcześniejsze, zagubionej części inwentarza, dotyczyły spraw zagranicznych, a zwłaszcza stosunków dyplomatycznych z cesarstwem, najbliższymi sąsiadami Pomorza (Brandenburgią, Saksonią, Meklemburgią i Polską) oraz z innymi dworami europejskimi. Obecnie tworzą one Pars I wspomnianego już zespołu, zob.: J. Podralski, Archiwum ..., oraz Archiwum Państwowe..., s. 19-33.

${ }^{61}$ AP w Szczecinie, , sygn. 65/2/0/3.18/III/424, s. 166-184.

${ }^{62}$ Ibidem, s. 101-102, 311.

${ }^{63}$ Analizując wielkość archiwum linii szczecińskiej Gryfitów, trzeba brać po uwagę fakt, że dzisiejsza liczba jednostek w zespole Archiwum Książąt Szczecińskich jest z jednej strony efektem strat, jakie poniósł zespół, zwłaszcza pod koniec II wojny światowej, ale z drugiej strony jest wynikiem kontynuacji wielu poszytów książęcych na początku przez administrację szwedzką, a potem brandenbursko-pruską oraz dołączania do zespołu akt wytworzonych w urzędach zarządzających Pomorzem w czasach szwedzkich i brandenbursko-pruskich praktycznie aż do końca XVIII w. Dzisiaj zespół Archiwum Książąt Szczecińskich, przechowywany w murach archiwum szczecińskiego, liczy 9142 j.a. (213 m.b.). Do tego trzeba jeszcze doliczyć 1500 j.a. znajdujących się w Landesarchiv Greifswald. 
W 1642 r. Szwedzi uporządkowali także Archiwum Książąt Wołogoskich, dzieląc je na 90 grup rzeczowych liczących łącznie 3797 j.a. ${ }^{64}$ Zawartość treściowa archiwaliów dotyczyła m.in.: problemów religii, stosunków z Rzeszą, rodziny książęcej, stosunków Księstwa Wołogoskiego z sąsiednimi krajami Szwecją, Danią oraz księstwami Rzeszy - spraw finansowych w tym utrzymania dworu, podatkowych, wojskowych, sejmików krajowych, a także stosunków z miastami księstwa, relacji z poddanymi, sporów granicznych oraz problemów związanych z zarządzaniem książęcymi domenami. Największą grupą rzeczową był wówczas titulus 60 liczący 314 j.a. odnoszących się do spraw wewnętrznych, w tym stosunków z poddanymi. Niewiele ustępował mu Titulus 63 zawierający 311 j.a. dotyczących problemów kościelnych i synodów. Do najmniejszych grup rzeczowych, liczących po 2 j.a., należały wówczas Titulusy: 15 - księstwo Pfaltz, 56 - miasto Franzburg oraz 57 - miasto Jarmen ${ }^{65}$.

Władze brandenburskie zaraz po zawarciu pokoju westfalskiego (1648 r.), kończącego wojnę trzydziestoletnią, domagały się podziału książęcych archiwaliów. Miało to brandenburskiej administracji ułatwiać zarządzanie przejętą częścią Pomorza. Ostatecznie dopiero po podpisaniu recesu granicznego (1653 r.) Szwedzi zdecydowali się przekazać Brandenburczykom część akt dotyczących elektorskiej części Pomorza (tzw. Pomorze Tylne - Hinter Pommern). Władze brandenburskie w październiku 1653 r. nakazały, aby akta dostarczone przez Szwedów ze Szczecina zostały przewiezione do Kołobrzegu (ówczesna stolica brandenburskiej części Pomorza), tworząc zalążek archiwum brandenburskiej części Pomorza. Zarządzono wówczas, że archiwalia na czas transportu powinny być złożone w odpowiednie skrzynie, a po przywiezieniu ich na miejsce należało je uporządkować, biorąc za podstawę przynależność registraturalną. Natomiast w ramach poszczególnych registratur akta powinny otrzymać nową przejrzystą strukturę wewnętrzną. Szczególnie ważne (jak podkreślano) było uporządkowanie akt sądowych ${ }^{66}$. Ponadto zalecano stworzenie odpowiednich pomocy ułatwiających odszukiwanie w archiwum potrzebnych władzom materiałów.

Podsumowując, trzeba podkreślić, że dopiero po śmierci Bogusława XIV poksiążęce akta zostały przez Szwedów w 1639 r. zgromadzone na szczecińskim zamku. W 1642 r. poddano je inwentaryzacji, a następnie uporządkowano. Gdy zakończyła się wojna trzydziestoletnia strona brandenburska zaczęła się domagać rozdziału akt poksiążęcych stosownie do uzyskanych po Gryfitach nabytków

\footnotetext{
Łącznie zachowane akta zespołu Archiwum Książąt Szczecińskich liczą dzisiaj 10642 j.a, spośród których tylko ok. 40 proc. powstało w czasach książęcych.

${ }^{64}$ Były to głównie akta XVI i XVII-wieczne: AP w Szczecinie, 65/11/0 Zbiór Samuela Gottlieba Loepera 1526-1790 [1863], sygn. 65/11/0/1/3, s. 180-583.

${ }^{65}$ Archiwum Książąt Wołogoskich liczy obecnie 2371 j.a., co daje łącznie 54,5 m.b. akt. Trzeba w tym miejscu dodać, że zespół ten nigdy po wymarciu linii wołogoskiej Gryfitów nie był kontynuowany przez administrację szwedzką bądź brandenbursko-pruską.

${ }^{66}$ AP w Szczecinie, sygn. 65/2/0/1.79/I/3096, s. 29-32.
} 
terytorialnych. Szwedzi w pierwszym okresie ignorowali te żądania. Dopiero po zawarciu recesu granicznego (1653 r.) i ostatecznym podziale Pomorza na część szwedzką i brandenburską, Szwedzi zdecydowali się oddać Brandenburczykom akta poksiążęce mogące im służyć do zarządzania nabytą częścią Pomorza. Wobec tego po 1653 r. na Pomorzu funkcjonowały dwa archiwa przechowujące akta z czasów książęcych. Pierwszym było archiwum działające przy szwedzkim gubernatorze Pomorza, umiejscowione na szczecińskim zamku, drugim archiwum brandenbursko-pomorskie w Kołobrzegu.

\section{Źródła}

Archiwum Państwowe w Szczecinie

65/2/0 Archiwum Książąt Szczecińskich [1209] 1354-1831, sygn. 65/2/0/1.50/I/1902, 65/2/0/1.51/I/1917, 65/2/0/1.51/I/1918, 65/2/0/1.51/I/1954, 65/2/0/1.51/I/1963, $65 / 2 / 0 / 1.51 / \mathrm{I} / 1965,65 / 2 / 0 / 1.51 / \mathrm{I} / 1975,65 / 2 / 0 / 1.79 / \mathrm{I} / 3096,65 / 2 / 0 / 1.79 / \mathrm{I} / 3152$, $65 / 2 / 0 / 1.79 / \mathrm{I} / 3160,65 / 2 / 0 / 1.80 / \mathrm{I} / 3359,65 / 2 / 0 / 1.80 / \mathrm{I} / 3359,65 / 2 / 0 / 1.80 / \mathrm{I} / 3359$, $65 / 2 / 0 / 1.84 / \mathrm{I} / 3886,65 / 2 / 0 / 1.94 / \mathrm{I} / 4639,65 / 2 / 0 / 1.99 / \mathrm{I} / 5194,65 / 2 / 0 / 3.18 / \mathrm{III} / 424$, $65 / 2 / 0 / 3.18 / \mathrm{III} / 425$.

65/3/0 Archiwum Książąt Wołogoskich [1401] 1532-1638 [1732], sygn. 65/3/0/29/403, 65/3/0/29/416, 65/3/0/29/525, 65/3/0/29/526.

65/11/0 Zbiór Samuela Gottlieba Loepera 1526-1790 [1863], sygn. 65/11/0/1/3.

65/16/0 Rękopisy i spuścizny 1321-1946, sygn. 65/16/0/61/644.

\section{Bibliografia}

Archiwum Państwowe w Szczecinie. Przewodnik po zasobie archiwalnym. Akta do 1945 r., oprac. R. Gaziński, P. Gut, M. Szukała, Warszawa-Szczecin 2002.

Bodaniak S., Kongres szczeciński na tle battyckiej polityki polskiej, Kraków 1929.

Gaziński R., W nowożytnym państwie pomorskim (1523-1653), [w:] Dzieje Koszalina, t. 1, do 1945 r, red. R. Gaziński, E. Włodarczyk, Koszalin 2016, s. 117-165.

Gwiazdowska E., Miasto w źródłach ikonograficznych, [w:] Dzieje Koszalina, s. 351-417.

Gut P., Sad Nadworny w Greifswaldzie w czasach szwedzkich i pruskich 1642-1849, „Szczeciński Informator Archiwalny” 2012, nr 21, s. 45-70.

Kozłowski K., Refleksje na sześćdziesięciolecie Archiwum Państwowego w Szczecinie. Tradycjaproblemy - ludzie, [w:] Mundus archii mundus memoriae. Archiwum Państwowe w Szczecinie 1945-2005, red. M. Frankel, Szczecin 2007, s. 9-20.

Kozłowski K., Szczecin i jego archiwum. Tradycja $i$ współczesność, [w:] Archiwa i archiwiści $w$ dobie spoleczeństwa informacyjnego. Pamiętnik IV Powszechnego Zjazdu Archiwistów Polskich, Szczecin 12-13 września 2002 r., t. 1, red. D. Nałęcz, Toruń 2002, s. 7-21.

Łazarek A., Wstęp do inwentarza zespołu: Archiwum Książat Wołogoskich, Szczecin 2003.

Medem v. L., Das Königliche Provinzialarchiv zu Stettin, „Zeitschrift für Archivkunde, Diplomatik und Geschichte", Bd 2, Hf. 1835, s. 2-50. 
Mundus archii mundus memoriae. Archiwum Państwowe w Szczecinie 1945-2005, red. M. Frankel, Szczecin 2007.

Podralski J., Wstęp do inwentarza zespołu: Archiwum Książat Szczecińskich, Szczecin 1977.

Podralski J., Archiwum Książą Szczecińskich. Przewodnik po zespole, cz. 1 i 2, Szczecin 1991.

Podralski J., Przysięga szczecińskiego nadwornego archiwisty z 1613 r., „Szczeciński Informator Archiwalny" 1996, nr 10, s. 9-11.

Pomerania. Kronika pomorska z XVI wieku (Thomasa Kantzowa), thum. K. Gołda, przypisy i komentarze T. Białecki, K. Gołda, E. Rymar, t. 1 i 2, Szczecin 2005.

Sąsiedzi w Europie. Księstwo Pomorskie i Królestwo Polskie (1000-1648). Nachbarn in Europa. Herzogtum Pommern und Königreich Polen (1000-1648), oprac. M. Schoebel, J. Macholak, P. Gut, U. Rodig, Kraków-Szczecin-Greifswald 2012.

Świadectwa historii Pomorza. Księstwo Pomorskie 1140-1648. Zeugnisse Pommerscher Geschichte. Herzogtum Pommern 1140-1648, red. K. Kozłowski, M. Schoebel, SzczecinGreifswald 1999. 